\title{
Intestinal Absorption of Glucose in Protein-deficient and in Starving Rats
}

\author{
BY H. HELLER \\ Department of Pharmacology, University of Bristol \\ (Received I I May 1954)
}

Disorders of the gastro-intestinal tract like diarrhoea, carbohydrate intolerance, vomiting, atrophy of the intestinal mucosa and the presence of undigested food have been frequently reported to occur in kwashiorkor, and in similar conditions outside Africa (Williams, r933; Carbelho, Pinto, Schmidt, Potsch \& Costa, 1945; Achar, 1950; Stransky, 1950; Soriano, 1950; Dean, 1952). It would, therefore, be interesting to know whether gastric and intestinal motility in these deficiency states are altered and whether the rate of absorption of food constituents is affected. In other words, whereas ample data on dietary patterns and methods of feeding in protein-deficient infants have been assembled (Brock \& Autret, 1952), information on the assimilation and utilization of foods is scanty. As an experimental approach to this problem the intestinal absorption of glucose was investigated in rats kept on various protein-deficient diets. Since anorexia figures prominently in clinical (Trowell, Davies \& Dean, 1952) and in experimental (Heller \& Blackmore, 1953) protein deficiency, some experiments were also performed on starving animals.

\section{Experimental animals}

\section{METHODS}

$33^{2}$ male albino rats, weighing from 1 10 to $3^{61} \mathrm{~g}$ were used.

\section{Diets}

Diets and water were unrestricted. The following diets were used:

(I) Stock diet (SS). The diet was that of Heller \& Blackmore (1953). All animals were kept on this diet for 4 weeks at least before an experimental diet was given.

(2) Control diet $(S E)$. The diet contained: casein $18 \cdot 0$, wheat starch $47^{\circ} \circ$, dried yeast 15.5, hardened groundnut oil 12.5, Steenbock salt mixture (Hawk \& Bergeim, I942) 4.0 , cod-liver oil $3.0 \%$, supplemented with $50 \mathrm{mg}$ vitamin B-complex powder (Crookes Laboratories Ltd.) (which contains thiamine $0.4 \%$, riboflavin $0.5 \%$, pyridoxin $0.18 \%$ and nicotinamide $4.0 \%$ ), and $6 \mathrm{mg}$ tocopheryl acetate/100 $\mathrm{g}$ diet. Sufficient water ( $30 \mathrm{ml} . / 100 \mathrm{~g})$ was added to give the mixture the consistency of a thick paste; the diet then yielded approximately $300 \mathrm{Cal} . / 100 \mathrm{~g}$.

(3) Protein-deficient diets. (a) Low-casein, high-carbohydrate diet (BA). It contained: casein 0.5 , wheat starch 80.0 , hardened groundnut oil $12 \cdot 5$, salt mixture $4^{\circ} \circ$, cod-liver oil $3.0 \%$; vitamin supplements and water were as for diet SE. The diet supplied approximately $300 \mathrm{Cal}$./ roo g. 
(b) Vegetable low-protein diet (TT). It contained: minced turnips $8 \mathrm{I} \cdot 5$, wheat starch $7 \cdot 0$, hardened groundnut oil 3.5 , cod-liver oil 4.0 , salt mixture $4.0 \%$. Vitamin supplements were as for diet SE. The diet had a protein equivalent of $0.4 \%$; it provided approximately roo Cal./100 g.

(c) Wet filter-paper diet (TC). This diet, used on the advice of Dame Harriette Chick, served as a control for diet TT and had approximately the same calorific value. Its composition was as follows: filter-paper 4.7 , water $76 \cdot 0$, casein $0 \cdot 8$, wheat starch $7 \cdot 0$, hardened groundnut oil 3.5 , cod-liver oil $4^{\circ} \circ$, salt mixture $4.0 \%$. Vitamin supplements were as for diet SE.

\section{Intestinal absorption of glucose}

Cori's (1925) technique was used with some slight modification. The rats were fasted for $24 \mathrm{~h}$ but water was only withdrawn $3 \mathrm{~h}$ before the experiment. Two ml. of a I M solution of glucose per $100 \mathrm{~g}$ body-weight were given by a stomach tube attached to a calibrated syringe and washed in with sufficient water to dilute the solution to $0.75 \mathrm{M}$ (Magee \& Reid, 1931). Forty-two min after the administration of glucose the animals were killed by a blow on the head and bleeding, and the gastro-intestinal tract was removed after the cardia and the rectum had been ligatured. In other groups, stomach and intestine were separated by a cut between ligatures at the pyloroduodenal junction. The stomach and intestine were placed in $600 \mathrm{ml}$. beakers, cut into short lengths, opened and washed four times with hot distilled water. The accumulated fluid was made up to $500 \mathrm{ml}$. Protein was precipitated with a sodium tungstatesulphuric acid mixture. Glucose was determined in portions in duplicate by the method of Shaffer \& Hartman (1920-I).

Syringes used for administration of the glucose solution were calibrated by estimating the glucose in volumes delivered. Washings of the gastro-intestinal tract of rats that had received water instead of glucose solution gave a 'glucose' value of less than $3 \mathrm{mg} / \mathrm{roo} \mathrm{ml}$. To guard against the possibility that food residue might modify glucose values obtained from gastro-intestinal washings, the 'glucose value' of the diets was estimated. Since it was less than $10 \mathrm{mg} / \mathrm{g}$, and the stomach and intestine contained on all occasions much less than $\mathrm{I} g$ of food debris, no correction for this was made.

\section{Glucose-tolerance curves}

The rats were prepared as for the estimations of intestinal absorption of glucose, and the same quantities of glucose relative to body-weight were given. Groups of six rats were used. Blood $(0.2 \mathrm{ml}$.) was taken from the tail vein before or at a given time after glucose administration, each animal being bled only once to avoid 'emotional' hyperglycaemia. Several groups of rats were treated in this manner and the mean of the blood-sugar values obtained at any given time was calculated. This procedure is thought to give reliable results but, since different animals have to be used for each point of the tolerance curve, it lacks discrimination. All.the experiments were begun at about 10 a.m. The blood sugar was estimated in duplicate in $0.1 \mathrm{ml}$. whole blood by the method of Hagedorn \& Jensen (1923). 


\section{Plasma-protein concentration}

A micro-Kjeldahl method and the specific-gravity method of Phillips, Van Slyke, Dole, Emerson, Hamilton \& Archibald (1945) were employed, using the formula of Hoch \& Marrack (I945) for the latter. Good agreement was obtained.

\section{Estimation of the water content of the intestinal wall}

Rats were deprived of food for $24 \mathrm{~h}$ and of drinking water for $3 \mathrm{~h}$. They were then killed by a blow on the head and bled. About 3 in. of the duodenum were removed and dried at $104^{\circ}$ for $48 \mathrm{~h}$.

\section{Histological investigation of intestines}

Rats for histological investigation were randomly selected from the same groups as animals used for experiments on glucose absorption. They were killed by a blow on the head and bleeding; the intestines were taken out, washed through with warm Ringer's solution, and two pieces each $3-4 \mathrm{~cm}$ in length taken from the upper, middle and lower part of the small intestine. In each instance one length was fixed whole, and the other cut open. To prevent the 'curling' of the intestine when it was opened these pieces of tissue were stretched out on thick filter-paper (cut from Whatman extraction thimbles) before being placed in the fixative. The fixatives used were formol saline and Susa; sections were stained with haematoxylin and eosin.

\section{Effect of the diets on body-weight}

RESULTS

Fig. I shows that the weight of rats kept on the control diet SE increased slowly whereas the weight of animals kept on the protein-deficient diets BA and TT decreased progressively. The weight curve of animals fed on diet $\mathrm{TC}$ resembled that of rats fed on diet TT. It seems likely that the latter curves were not a true record of the loss of body solids since there is evidence (Dicker, Heller \& Hewer, 1946; Dicker, 1950) that animals on such a deficient diet retain water and sodium. Owing to progressive anorexia, the supply of a protein-deficient diet equi-calorific with the control diet SE did not prevent substantial losses in body-weight.

\section{Intestinal absorption of glucose}

In a series of preliminary experiments Cori's 'absorption coefficient' (mg glucose absorbed $/ 100 \mathrm{~g} / \mathrm{h}$ ) was $382 \pm 8.5$ (standard error of the mean) in twelve control rats on diet SE with a mean plasma-protein concentration of $7 \cdot 2 \pm 0.71 \mathrm{~g} / 100 \mathrm{ml}$., and $269 \pm 9 \cdot 2$ in eleven rats kept on the vegetable protein-deficient diet TT (mean loss of bodyweight $=42 \cdot 7 \pm 1 \cdot 67 \%$, mean plasma-protein concentration $=5.5 \pm 0.05 \mathrm{~g} / 100 \mathrm{ml}$.), suggesting a marked decrease in the rate of glucose absorption in the protein-deficient animals. However, these results did not show whether the absorption coefficient was lower in the protein-deficient rats because more glucose had been retained in the stomach (from which, according to Macleod, Magee \& Purves (1930), Maddock, Trimble \& Carey (1933) and Fenton (1945) it is not absorbed), or less had been absorbed from the intestine, or both. Therefore, glucose in the stomach and in the 
intestine were estimated separately. Rats on different protein-deficient diets were used when the decreases in body-weight and in the plasma-protein concentration were approximately the same in each series.

Table I shows that the mean amount of glucose emptied from the stomach was significantly decreased in rats on diets BA, TT and TC, and also that less of the glucose available in the intestine was absorbed by these animals.

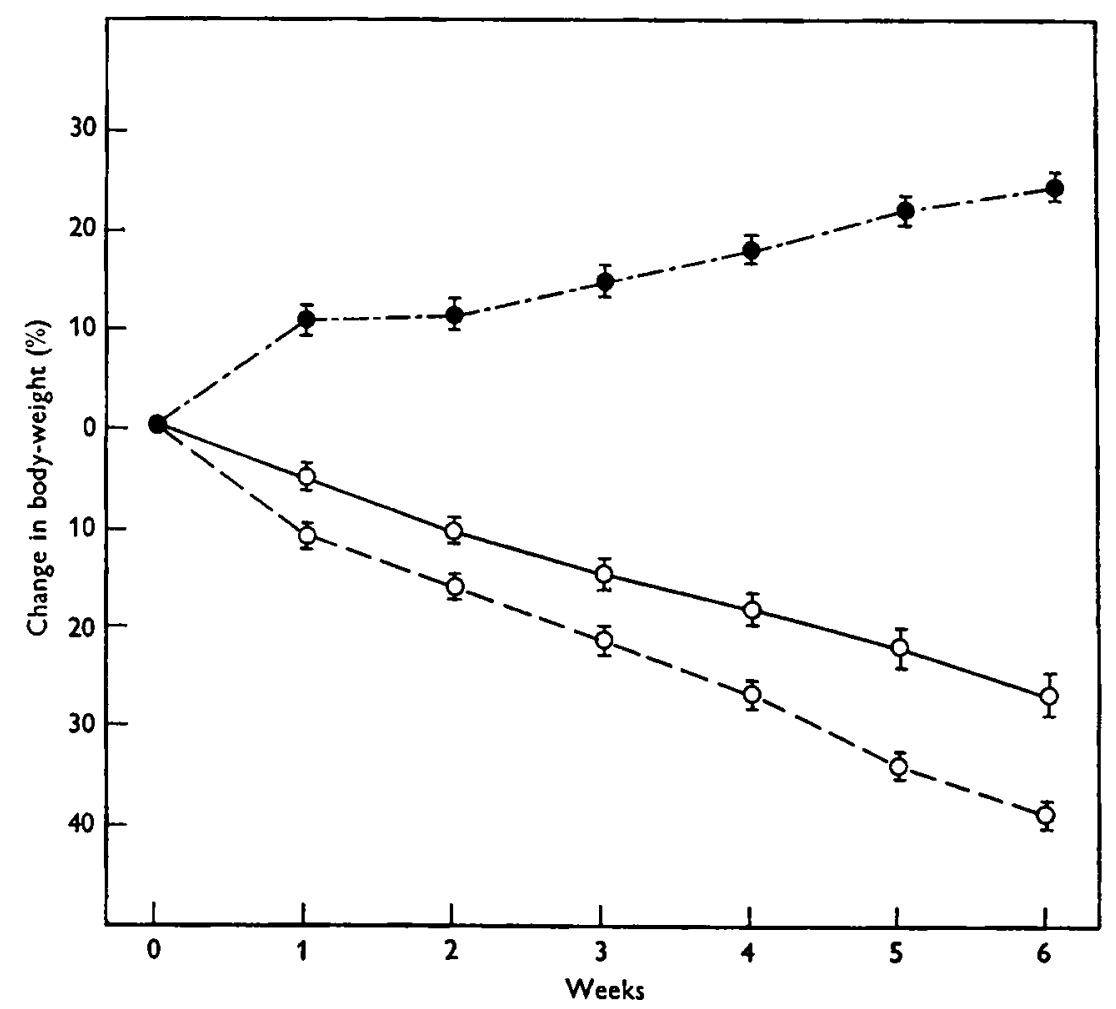

Fig. I. Effect of protein-deficient diets on the body-weight of rats. $O-0$, low-casein, high-carbohydrate diet $\mathrm{BA} ; \mathrm{O} \ldots \mathrm{O}$, vegetable low-protein diet TT;.... , control diet SE. Mean values with their standard errors are given by appropriate modification of these symbols for groups of ten rats. Rats on the filter-paper diet TC gave a weight curve similar to that obtained with diet TT.

It may be objected that the differences between the controls and the animals on protein-deficient diets were due to the smaller amounts of glucose given to the latter. A group of control rats was therefore treated as if they had suffered approximately the same loss of body-weight as the protein-deficient animals, i.e. these controls received amounts of glucose that were $35 \%$ lower than their actual weight would have required. Table I shows that the smaller glucose load did not alter the residual gastric load or the relative amounts of absorbed glucose.

The rats on diets BA, TT and TC did not suffer only from protein deficiency but, owing to anorexia and the low calorific value of diets TT and TC, also from a decreased intake of calories. Since low absorption coefficients have been reported in starving rats (Cori, 1927-8; Horne, McDougall \& Magee, 1933-4; Marrazzi, 1940-1) the absorp- 


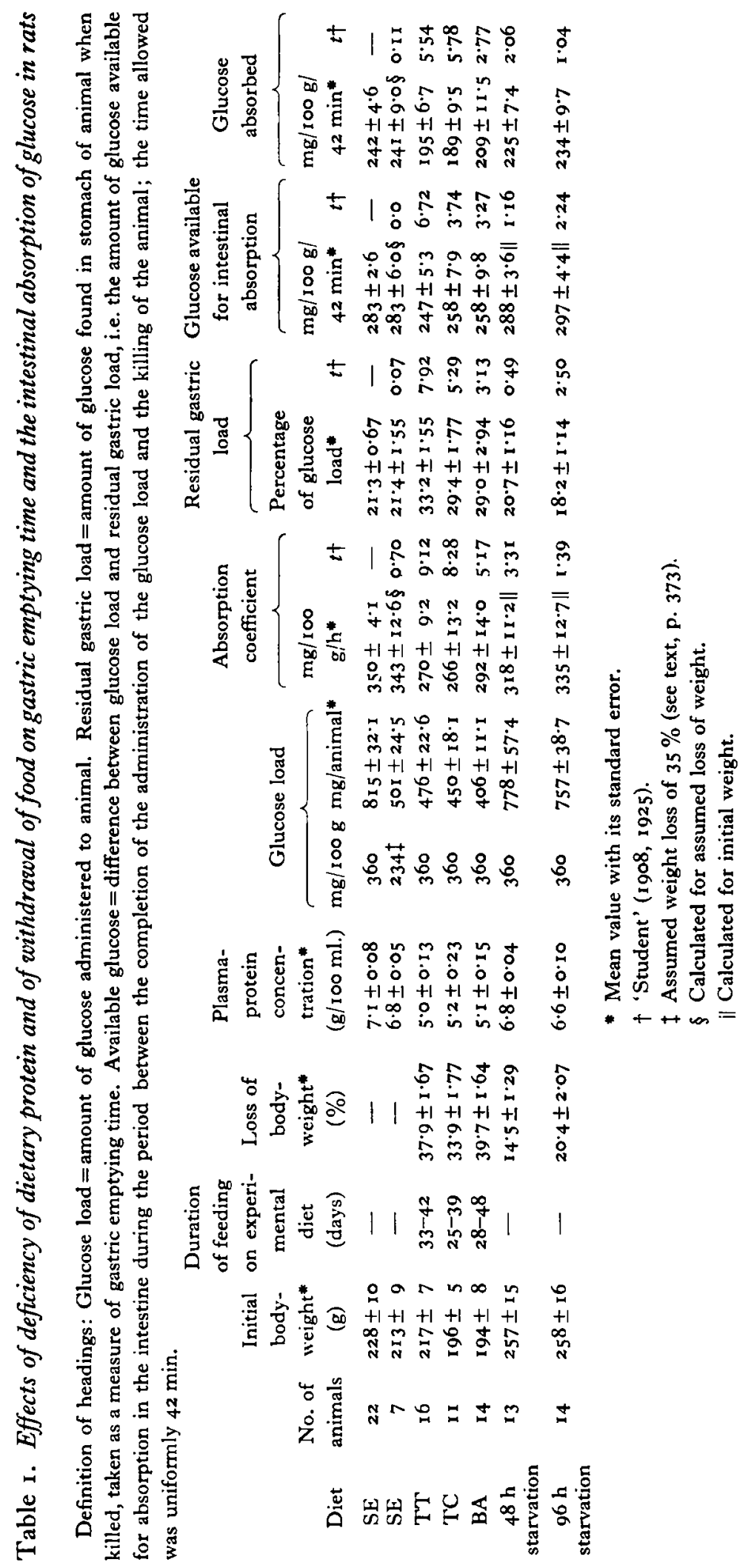


tion of glucose in rats from which food (but not water) had been withheld for 48 and $96 \mathrm{~h}$ was investigated. Table I shows that, after withdrawal of food for $48 \mathrm{~h}$, the mean amount of glucose emptied from the stomach was much the same as in controls on diet SE but that glucose absorption from the intestine was significantly decreased. When rats were starved for $96 \mathrm{~h}$ it was found (Table $\mathrm{I}$ ) that in most animals glucose left the stomach more quickly than in either the controls or in animals starved for $48 \mathrm{~h}$. However, the mean amount of glucose absorbed in the standard period was not significantly decreased. A somewhat different picture is obtained when the percentage of

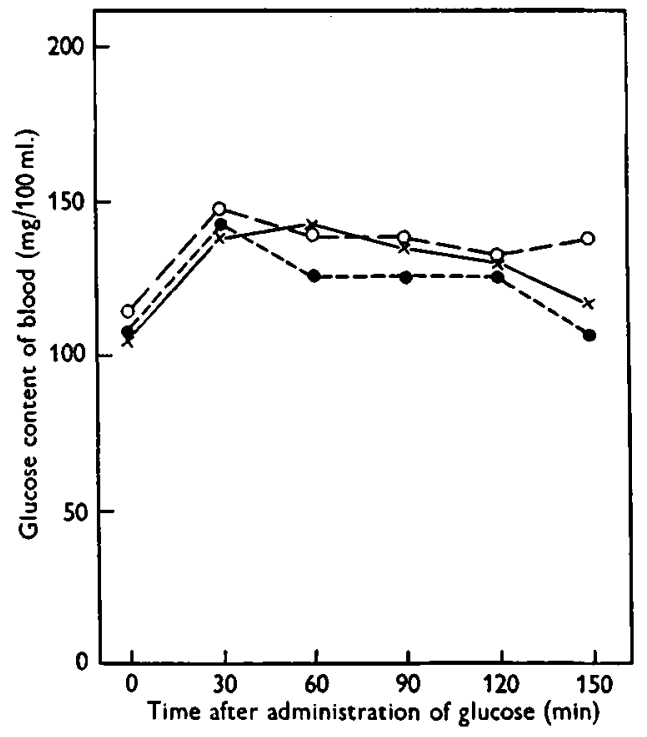

Fig. 2

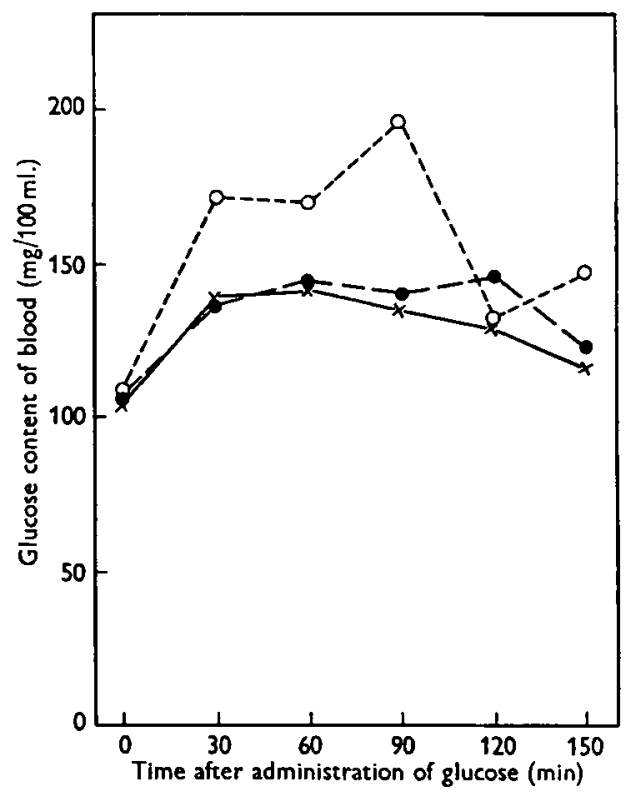

Fig. 3

Fig. 2. Alimentary glucose-tolerance tests in rats on protein-deficient diets. $\times-\times$, diet $\mathrm{SE}$ (controls); -.. diet TT; $0--0$, diet BA. Each point on the curves represents the mean of six determinations in six rats. For further details see text.

Fig. 3. Alimentary glucose-tolerance tests in starving rats. $\times-\times$, diet SE (controls); - -, $48 \mathrm{~h}$ starvation; $O_{--}-0,96 \mathrm{~h}$ starvation. Each point on the curves represents the mean of six determinations in six rats. For further details see text.

'available glucose absorbed' is calculated; the mean figure in the controls was $85.5 \pm 1 \cdot 01 \%$, that in rats starved for $48 \mathrm{~h} 78 \cdot 0 \pm \mathrm{I} \cdot 76 \%\left(t^{*}=3.996\right)$ and that in animals starved for $96 \mathrm{~h} 78 \cdot \mathrm{I} \pm 2 \cdot 03 \%$. In other words the fraction of the available glucose absorbed was the same in the two starvation series.

\section{Glucose 'tolerance' in protein-deficient and in starving rats}

Figs. 2 and 3 show glucose-tolerance curves in protein-deficient and in starving rats. The slopes of the ascending parts of the curves, the height of blood-sugar levels reached and the duration of the alimentary hyperglycaemia were much the same in the animals on the diets BA and TT as in those on the control diet SE. Likewise, there 
was little difference between the controls and rats from which food had been withheld for $48 \mathrm{~h}$ but a steeper initial rise and a markedly exaggerated hyperglycaemic response was present in rats starved for $96 \mathrm{~h}$ (Fig. 3).

\section{Water content of the intestinal wall}

The mean water content of pieces of duodenum was $78 \cdot 7 \pm 0.63 \%$ (fourteen animals) in rats kept on the control diet SE, $78.6 \pm 0.40 \%$ (ten animals) in rats on the vegetable protein-deficient diet TT and $8 \mathrm{I} \cdot 2 \pm 0.35 \%$ (twelve animals) in rats on the low-casein, high-carbohydrate diet BA. The difference between the water content of the intestines of rats kept on diet TT and that of the controls was negligible $(t=0.12, P>0.9)$, but that between the water content of the intestines of the controls and of the rats on diet BA was significant $(t=3.34, P<0.01)$. The period for which these animals had been kept on the experimental diet and the mean losses of body-weight of the proteindeficient rats were comparable with those of animals in which intestinal absorption of glucose was estimated.

Table 2. Details of animals used for histological investigation of small intestine

$\begin{array}{lccccc}\text { Diet } & \begin{array}{c}\text { No. of } \\ \text { animals }\end{array} & \begin{array}{c}\text { Initial } \\ \text { body-weight } \\ (\mathrm{g})\end{array} & \begin{array}{c}\text { Duration of } \\ \text { feeding on } \\ \text { experimental } \\ \text { diet (days) }\end{array} & \begin{array}{c}\text { Loss of } \\ \text { body-weight } \\ (\%)\end{array} & \begin{array}{c}\text { Mean plasma- } \\ \text { protein } \\ \text { concentration } \\ \text { when killed } \\ (\mathrm{g} / \text { roo ml.) }\end{array} \\ \text { SS } & 6 & - & - & - & 6 \cdot 8 \\ \text { TT } & 6 & 170-250 & 21-37 & 23-48 & 5 \cdot 2 \\ \text { TC } & 3 & 170-200 & 35 & 30-36 & 5 \cdot 3 \\ \text { BA } & 6 & 110-125 & 34-50 & 26-47 & 4 \cdot 6 \\ \text { BA } & 8 & 165-220 & 34-50 & 26-47 & 4 \cdot 9 \\ \text { BA } & 10 & 270-330 & 46-48 & 26-37 & 5 \cdot 0\end{array}$

Histological observations on the intestine of protein-deficient and of starving rats

Information on the protein-deficient animals investigated is given in Table 2. In addition three rats were starved for $48 \mathrm{~h}$ at $18.5^{\circ}$. Since it has been reported (Sun, 1926-7) that starvation at low environmental temperatures is more liable to produce intestinal lesions, three rats were starved for $24 \mathrm{~h}$ at $8-10^{\circ}$, and another three for $48 \mathrm{~h}$ at $5^{\circ}$. The initial weight of the 'starved rats' varied from 250 to $260 \mathrm{~g}$ and the loss of weight from 14 to $19 \%$. Dr Marion O. P. Wiltshire, who supervised the preparation of the histological specimens, gave the following report:

'The histological appearance of the small intestines of the experimental animals does not differ in any way from that of the normal controls. Neither of the diets produced pathological change in the mucosa. Extreme degrees of muscular atrophy can be excluded though minor degrees may have been masked by variation in the tone of the muscle before and on fixation. The age and initial weight of the animal does not make any difference to these results. In some of the control animals there is a small amount of sloughing away of the epithelium at the tips of the villi; this is also seen in some of the experimental animals but to no greater degree than in the controls. One of the animals starved for $48 \mathrm{~h}$ at $5^{\circ}$ was found dead in its cage, and this gut shows great damage; in some parts the whole of the mucosa is destroyed, whilst other parts show 
desquamation of the villi. This is the only animal to show any variation from normal; the damage was probably post mortem. In the two other rats which were treated in the same way and which showed a comparable loss of weight, the small intestine is quite normal.'

\section{DISCUSSION}

The results on fasting rats confirm the conclusions of Cori (193r): an oral glucose load disappeared from the gastro-intestinal tract more slowly after $48 \mathrm{~h}$ than after $24 \mathrm{~h}$ of starvation. When the period of fasting was extended to $96 \mathrm{~h}$ the mean amounts of glucose absorbed increased again. These results became clearer when the rate of disappearance of a standard glucose load from the stomach of starving animals was investigated. The mean residual gastric load of glucose at a given time after administration to rats starved for $48 \mathrm{~h}$ did not differ significantly from that of the controls, but the mean amounts of glucose discharged from the stomach increased when rats were fasted for $96 \mathrm{~h}$.

The fraction of 'available glucose' (i.e. glucose emptied into the intestine) absorbed after starvation for $96 \mathrm{~h}$ remained much the same as that in animals starved for $48 \mathrm{~h}$. That is to say, it was well below the fraction absorbed by the controls but, as, owing to the decreased gastric emptying time, more glucose was available, the absolute amounts absorbed after $96 \mathrm{~h}$ of fasting approached the figures for the control series.

Whether the decrease in the rate of absorption in starving animals was due to changes in intestinal peristalsis, changes in glucose translocation or glucose utilization of the intestinal wall (Fisher \& Parsons, 1950a), or a combination of these factors, cannot be decided from the results presented. All that can be said is that, contrary to the findings of Sun (1926-7) in mice, no histologically demonstrable lesions were found in the small intestine of the fasting animals. The results of Thaysen \& Thaysen (1949), who found epithelial changes in the small intestine of starving rats, are not strictly comparable since their animals were deprived of food for 4 days.

Glucose-tolerance curves in starving rats showed no clear difference between controls and animals deprived of food for $48 \mathrm{~h}$. An exaggerated hyperglycaemic response was seen in rats starved for $96 \mathrm{~h}$. Since the absolute amounts of glucose absorbed were not significantly different from those in the controls this response can be assumed to have been mainly determined by extra-alimentary factors.

The results in animals on protein-deficient diets differ from those obtained in fasting animals in showing that the discharge of glucose from the stomach was significantly retarded. This observation would agree with that of Mecray, Barden \& Ravdin (1937) who found a delay in gastric emptying time in hypoproteinaemic dogs, but it differs from the results of Beams, Free \& Leonards (1944) who failed to find it in dogs with oedema and associated similarly low plasma-protein values. However, whereas Mecray and his co-workers produced hypoproteinaemia by plasmaphoresis as well as by nutritional means, Beams et al. used plasmaphoresis only. These observations together with those presently reported suggest that it is not the low plasma-protein level and the oedema as such which retard gastric emptying, but rather the prolonged dietary deficiency of protein with the concurrent anorexia. 
Glucose absorption from the intestine (again referred to available glucose, i.e. to glucose discharged from the stomach) was somewhat decreased in the rats on proteindeficient diets, but apparently not sufficiently to influence alimentary glucosetolerance curves markedly. Judging from the reports of Barden, Thompson, Ravdin \& Frank (1938) and Berridge (1951), decreased motility of the small intestine in protein deficiency can be expected. If so, and if this implicates the propulsion of glucose solutions, more glucose per unit time should have been absorbed by the proteindeficient animals, since the rate of absorption in normal rats diminishes with the distance from the pylorus (Fisher \& Parsons, 1950 $a, b$ ). The impairment of glucose absorption is thus more likely to have been due to a decrease of glucose translocation or utilization. Oedema of the intestinal wall was probably not a decisive factor, since no relationship was found between the water content of intestinal tissue and the decrease in glucose absorption. Atrophy (i.e. loss of mass) of the intestine in animals which lost up to $40 \%$ of their initial body-weight may have been important in decreasing glucose utilization. Whether the function of the intestinal epithelium was impaired cannot be decided from this investigation; histological examination of the epithelium showed no abnormality.

\section{SUMMARY}

I. Intestinal glucose absorption was studied by Cori's (1925) method in rats fed on three protein-deficient diets and in rats that had been fasted for $48 \mathrm{~h}$ and for $96 \mathrm{~h}$.

2. The mean amounts of glucose that disappeared from the gastro-intestinal tract during a standard period were reduced in protein-deficient animals. When the disappearance of glucose from the stomach and from the intestine was measured separately, it was found that the discharge of glucose from the stomach was significantly delayed. In addition there was some decrease in the rate of absorption of glucose from the intestine.

3. Alimentary glucose-tolerance curves in the rats on protein-deficient diets did not differ substantially from those obtained in controls.

4. Intestinal glucose absorption in rats starved for $48 \mathrm{~h}$ was decreased; there was no delay in gastric emptying time. Rats deprived of food for $96 \mathrm{~h}$ showed in most instances an accelerated discharge of glucose from the stomach; the absolute amounts absorbed from the intestine were much the same as those in the controls.

5. Glucose-tolerance curves in rats starved for $48 \mathrm{~h}$ were similar to those obtained in controls. Rats starved for $96 \mathrm{~h}$ showed a markedly exaggerated hyperglycaemic response.

6. No histologically demonstrable abnormalities were found in the small intestine of the rats fed on the protein-deficient diets or of animals that had been deprived of food for $48 \mathrm{~h}$.

My sincere thanks are due to Dr Marion O. P. Wiltshire who was responsible for the histological part of this investigation. I am indebted to Mr K. E. Blackmore and $\mathrm{Mr}$ E. Savory for technical assistance and to Crookes Laboratories Ltd. for the supply of the vitamin B-complex powder. 


\section{REFERENCES}

Achar, S. T. (1950). Brit. med. F. i, 701.

Barden, R. P., Thompson, W. D., Ravdin, I. S. \& Frank, I. L. (1938). Surg. Gynec. Obstet. 66, 819.

Beams, A. J., Free, A. H. \& Leonards, J. R. (1944). Arch. intern. Med. 73, 397.

Berridge, F. R. (1951). In Spec. Rep. Ser. med. Res. Coun., Lond., no. 275, p. 97.

Brock, J. F. \& Autret, M. (1952). FAO nutr. Stud. no. 8.

Carbelho, M. J., Pinto, A. S., Schmidt, M. M., Potsch, M. \& Costa, C. (1945). F. Pediat. (Rio de Y.), II, 395.

Cori, C. F. (1925). F. biol. Chem. 66, 691.

Cori, C. F. (1927-8). Harvey Lect. $23,76$.

Cori, C. F. (1931). Physiol. Rev. Ir, 143.

Dean, R. F. A. (1952). Brit. med. F. ii, 791.

Dicker, S. E. (1950). Biochem. $7.46,53$.

Dicker, S. E., Heller, H. \& Hewer, T. F. (1946). Brit. F. exp. Path. 27, 158.

Fenton, P. F. (1945). Amer. F. Physiol. 144, 609.

Fisher, R. B. \& Parsons, D. S. (1950a). F. Physiol. r10, 28 r.

Fisher, R. B. \& Parsons, D. S. (1950b). Y. Anat., Lond., 84, 272.

Hagedorn, H. C. \& Jensen, B. N. (1923). Biochem. Z. 135, 46.

Hawk, P. B. \& Bergeim, O. (1942). Practical Physiological Chemistry, i ith ed. London: Churchill. Heller, H. \& Blackmore, E. K. (1953). Brit. F. Nutr. 7, 349.

Hoch, H. \& Marrack, J. (1945). Brit. med. F. ii, I51.

Horne, E. A., McDougall, E. J. \& Magee, H. E. (1933-4). F. Physiol. 8o, 48.

Macleod, J. J. R., Magee, H. E. \& Purves, C. B. (1930). F. Physiol. 70, 404.

Maddock, S. J., Trimble, H. C. \& Carey, B. W. (1933). F. biol. Chem. 103, 285.

Magee, H. E. \& Reid, E. (I93 г). F. Physiol. 73, 163.

Marrazzi, R. (1940-1). Amer. Y. Physiol. 131, 36.

Mecray, P. M., Barden, R. P. \& Ravdin, I. S. (1937). Surgery, 1, 53.

Phillips, R. A., Van Slyke, D. D., Dole, V. P., Emerson, K., Hamilton, P. B. \& Archibald, R. M. (I945). Copper Sulfate Method for Measuring Specific Gravities of Whole Blood and Plasma. New York: Josiah Macy Foundation.

Shaffer, P. A. \& Hartman, A. F. (1920-1). F. biol. Chem. 45, 349.

Soriano, M. (1950). Med. clin. (Barcelona), 15, 153.

Stransky, E. (1950). Brit. med. J. i, 1370.

'Student' (1908). Biometrika, 6, I.

'Student' (r925). Metron. 5, 105.

Sun, T. P. (1926-7). Anat. Rec. 34, 341.

Thaysen, E. H. \& Thaysen, J. H. (1949). Acta path. microbiol. scand. 26, 370.

Trowell, H. C., Davies, J. N. P. \& Dean, R. F. A. (1952). Brit. med. J. ii, 798.

Williams, C. D. (1933). Arch. Dis. Childh. 8, 423.

Woodman, H. E. (1952). Bull. Minist. Agric., Lond., no. 48, 12th ed. 